\title{
UTILIZING CHERNOFF FACES IN MODELING RESPONSES IN THE EVALUATION OF TRIMESTER SCHEME IMPLEMENTATION
}

\author{
Rosie C. Lopez-Conde ${ }^{a}$, Jenina N. Nalipay ${ }^{\text {a }}$, Inero V. Ancho ${ }^{a^{*} \text {, }}$ \\ Edna Luz R. Abulon ${ }^{a}$, Teresita T. Rungduin ${ }^{a}$, Ma. Antoinette C. Montealegre ${ }^{a}$, \\ Jonathan A. Madronero ${ }^{b}$ \\ ${ }^{a}$ Philippine Normal University, Manila, Philippines \\ ${ }^{b}$ Philippine Science High School, General Santos City, Philippines \\ *Corresponding author: Email: ancho.iv@pnu.edu.ph \\ Article history \\ Received: June $30^{\text {th }}, 2021$ \\ Received in revised form: October $20^{\text {th }}, 2021 \mid$ Accepted: October $21^{\text {st }}, 2021$ \\ Available online: January $27^{\text {th }}, 2022$
}

\begin{abstract}
This study uses Chernoff faces to model the responses of students, faculty, and administration staff of a teacher education institution in Manila, Philippines, to the implementation of an Outcomes-Based Teacher Education Curriculum (OBTEC) trimester scheme. Chernoff faces provide a valuable representation to model responses because people are used to studying and reacting to faces. This study used a quantitative research method by analyzing crosssectional data from the study of the OBTEC trimester scheme. A total of 322 participants were selected through convenience sampling and given a 15-item survey in which possible responses ranged from 1 (strongly disagree) to 6 (strongly agree). The administrators were found to give a generally favorable rating (overall mean $=4.56$ agree; overall $S D=0.45$ ) to the OBTEC trimester scheme. The statements most highly rated by the administrators pertain to the success of OBTEC in integrating pedagogical content knowledge training with outcomes-based education, preparation of the students for the teaching profession, and consistency with the K to 12 curriculum. These responses are characterized by the structure of the face, the width of the mouth, and the height of the face, respectively. The most negative aspects of the OBTEC trimester scheme, according to the students, are characterized by hair height, nose width, and a hair style of thin hair that points downward. Chernoff faces were found to be a simple, yet powerful tool to model responses in the evaluation of the OBTEC trimester scheme.
\end{abstract}

Keywords: Chernoff's faces; Modeling responses; Trimester Scheme evaluation.

DOI: http://dx.doi.org/10.37569/DalatUniversity.12.1.920(2022)

Article type: (peer-reviewed) Full-length research article

Copyright (C) 2022 The author(s).

Licensing: This article is licensed under a CC BY-NC 4.0 


\section{INTRODUCTION}

The Chernoff Faces procedure, involving the assignment of variables in a data set to the features of a human face, has been incorporated into many statistics and statistical graphic representation packages. It is both cogent and flexible, and can be tailored to suit the prerequisites of almost any data set. The Chernoff Faces representation technique has been applied in a wide range of academic disciplines and applied fields (Pitt et al., 2011, p. 4).

There are many ways to present research findings. Most often, tables and charts are used to show the values derived from statistical analyses. However, some readers, especially those with limited knowledge of statistics, might find these difficult to understand, which defeats the main purpose of communicating research results. Chernoff faces are an alternative way of presenting results that can facilitate understanding by even those with limited statistical knowledge. According to Chen $(2017$, p. 1), strategies showcasing data are performed through "data characteristics, visualization purposes, computing capacity, or even target audience."

Zhang et al. (2017) investigated the applicability and efficiency of using Chernoff faces in the context of automatic welding quality classification. Their study further validates the use of pattern features of the images. In the context of software, Moiz and Rao (2020) have identified 15 images of Chernoff faces to classify code behaviors that were eventually found to be $95 \%$ accurate. Chernoff faces are also used for the input of higher dimensional data (VanHoudnos et al., 2017). Teke et al. (2020) employed Chernoff faces to interpret theoretical and practical aspects of livestock data. Guha and Assaf (2019) have also established the efficiency of using Chernoff faces in interpreting voluminous data that need representation.

The fundamental reason for using Chernoff faces according to Nuñez (2013) is that people can easily recognize distinct facial characteristics and can notice even small and subtle changes in facial features.

This paper focuses on using Chernoff faces to represent the responses of students, faculty members, and administrators of a teacher education institution in Manila, Philippines, to implementation of an Outcomes-Based Education (OBE) trimester scheme. Chernoff (1973) generated up to 18 distinct facial parameters to visualize data. These facial features ranged from nose length and eye size to facial width and eccentricity of the lower face (Soininvaara, 2013). Mateos et al. (2018, p. 77) also supported the possibility of using Chernoff faces to "visualize through the facial features in detail the presence of students' engagement."

One of the unique characteristics of the institution is the trimester scheme, as opposed to the usual semester cycle in the Philippine higher education context. Lastly, as one of the first institutions in the country to fully implement the OBTEC, the institution becomes the most appropriate locale for the study. 
The main objective of the study is to utilize Chernoff faces in modeling responses to the implementation of the OBTEC trimester scheme.

This study specifically aims to:

1. Use Chernoff faces to visualize the responses of students, faculty, and administrators grouped according to

1.1. student year level and program,

1.2. faculty and institute,

1.3. administrative position,

1.4. faculty years of teaching, and

1.5. faculty rank.

2. Use Chernoff faces to propose recommendations on the issues that concern students, faculty, and administrators regarding the implementation of the OBTEC trimester scheme.

\section{METHODOLOGY}

This study uses cross-sectional data consisting of responses to the OBTEC trimester scheme. The participants were students under the OBTEC, faculty members who taught OBTEC classes, and administrators who worked during the implementation of the OBTEC. A total of 322 participants (298 students, 19 faculty members, and 5 administrators) were selected through convenience sampling. The sample size represents the number of individuals who participated in the study.

The instrument used to assess the OBTEC trimester scheme was developed by the researchers. It is a 15-item survey with a rating scale from 1 (strongly disagree) to 6 (strongly agree) (Appendix 1). The survey was administered to students, faculty members, and administrators online using Google Forms. This study is an output of the students, faculty members, and administrators who expressed willingness to participate in the study.

The cross-sectional data obtained in the study were analyzed with Chernoff faces using the $\mathrm{R}$ statistical software package. Variables were assigned by the researchers using the corresponding facial feature variation allocations shown in Table 1. 


\section{Table 1. Facial feature variations for Outcomes-Based Education trimester characteristics}

\begin{tabular}{|c|c|}
\hline Variable Characteristics & Facial Feature Variation Allocations \\
\hline $\begin{array}{l}\text { Consistency with the K-12 } \\
\text { curriculum }\end{array}$ & $\begin{array}{l}\text { Height of face - the longer the face, the higher the level of agreement to } \\
\text { consistency with the K-12 curriculum. }\end{array}$ \\
\hline $\begin{array}{l}\text { Mastery of required } \\
\text { competencies }\end{array}$ & $\begin{array}{l}\text { Width of face - the wider the face, the higher the level of agreement to } \\
\text { mastery of required competencies. }\end{array}$ \\
\hline $\begin{array}{l}\text { Integrates training in PCK } \\
\text { with OBE }\end{array}$ & $\begin{array}{l}\text { Structure of face - the more formed the structure of the face, the higher the } \\
\text { level of agreement to the integration of PCK with OBE. }\end{array}$ \\
\hline Preparedness for BLEPT & $\begin{array}{l}\text { Height of mouth - the longer the mouth, the higher the level of agreement } \\
\text { to preparedness for BLEPT. }\end{array}$ \\
\hline $\begin{array}{l}\text { Students' preparedness for } \\
\text { the teaching profession }\end{array}$ & $\begin{array}{l}\text { Width of mouth - the wider the mouth, the higher the level of agreement } \\
\text { to students' preparedness for the teaching profession. }\end{array}$ \\
\hline $\begin{array}{l}\text { Complements actual } \\
\text { contact time }\end{array}$ & $\begin{array}{l}\text { Smiling - the greater the curvature of the smile, the higher the level of } \\
\text { agreement to complementation with actual contact time. }\end{array}$ \\
\hline $\begin{array}{l}\text { Innovation to traditional } \\
\text { learning }\end{array}$ & $\begin{array}{l}\text { Height of eyes - the longer the eyes, the higher the level of agreement to } \\
\text { innovation to traditional learning. }\end{array}$ \\
\hline $\begin{array}{l}\text { Application to what was } \\
\text { learned }\end{array}$ & $\begin{array}{l}\text { Width of eyes - the wider the eyes, the higher the level of agreement to the } \\
\text { application to what was learned. }\end{array}$ \\
\hline $\begin{array}{l}\text { Allows efficient use of } \\
\text { time }\end{array}$ & $\begin{array}{l}\text { Height of hair - the longer the hair, the higher the level of agreement to } \\
\text { allowing efficient use of time. }\end{array}$ \\
\hline $\begin{array}{l}\text { Allows objectives to be } \\
\text { met }\end{array}$ & $\begin{array}{l}\text { Width of hair - the wider the hair the higher the level of agreement to } \\
\text { allowing objectives to be met. }\end{array}$ \\
\hline $\begin{array}{l}\text { Provides time to complete } \\
\text { requirements }\end{array}$ & $\begin{array}{l}\text { Style of hair - the bigger the volume of hair and if pointing upward, the } \\
\text { higher the level of agreement to providing time to complete requirements; } \\
\text { otherwise, the lesser the volume of hair and if pointing downward, the } \\
\text { lower the level of agreement. }\end{array}$ \\
\hline $\begin{array}{l}\text { Better appreciation of } \\
\text { learning }\end{array}$ & $\begin{array}{l}\text { Height of nose - the longer the nose, the higher the level of agreement to } \\
\text { the appreciation of learning. }\end{array}$ \\
\hline School-life balance & $\begin{array}{l}\text { Width of nose - the wider the nose, the higher the level of agreement to } \\
\text { school-life balance. }\end{array}$ \\
\hline $\begin{array}{l}\text { Students' motivation to do } \\
\text { well in studies }\end{array}$ & $\begin{array}{l}\text { Width of ears - the wider the ears, the higher the level of agreement to } \\
\text { students' motivation to do well in studies. }\end{array}$ \\
\hline $\begin{array}{l}\text { Experience academic } \\
\text { satisfaction }\end{array}$ & $\begin{array}{l}\text { Height of ears - the longer the ears, the higher the level of agreement to } \\
\text { experiencing academic satisfaction. }\end{array}$ \\
\hline
\end{tabular}

The "ideal" (maximum) and "extreme" (minimum) case faces are shown in Figure 1. As shown in the figure, the ideal response to OBE and the trimester scheme would have a fat face, thick hair, large round eyes with round pupils, a large broad nose, and a broadly smiling mouth. On the other hand, the face representing the least agreement with the OBTEC trimester scheme would have thin or narrow features. 


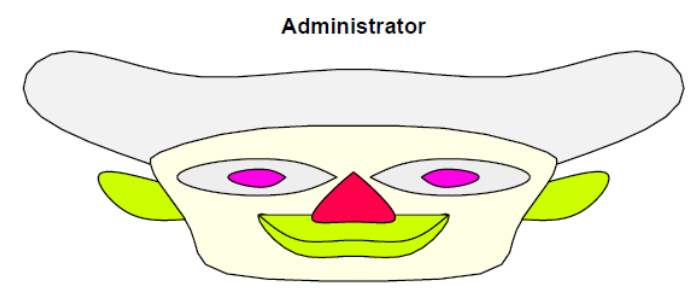

Student

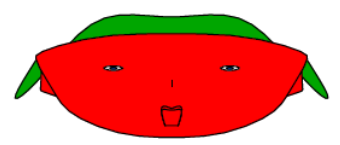

Figure 1. Maximum (administrator) and minimum (student) value faces

\section{RESULTS AND DISCUSSION}

\subsection{Student year levels and programs}

A total of 298 student respondents from various OBTEC teacher education programs completed the survey regarding the OBTEC trimester scheme. The students have a mean age of $20.36(\mathrm{SD}=10.58)$. The majority were females in their fourth year of the program. Overall, the students found the OBTEC trimester scheme somewhat unfavorable (overall mean $=3.38$ somewhat disagree; overall $\mathrm{SD}=0.15$ ). Student responses by year level can be differentiated using Chernoff faces, as shown in Figure 2.

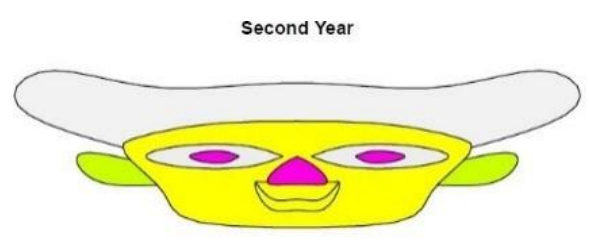

Fourth Year

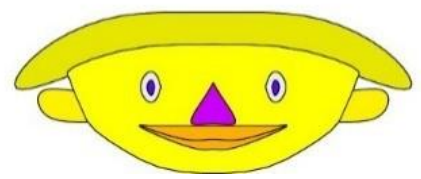

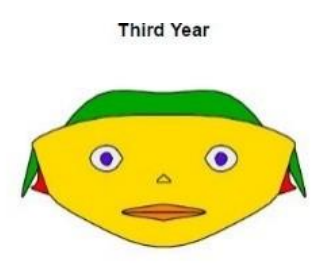

Irregular/Extended more than 5 years

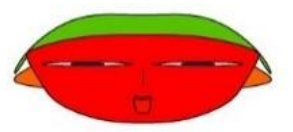

Figure 2. Chernoff faces for student year levels

The responses of the second- and fourth-year students are characterized by "ideal" faces. Among the aspects of the OBTEC trimester scheme, the most positive responses by students are that the curriculum is consistent with the $\mathrm{K}$ to 12 curriculum, that it prepares them for the teaching profession, and that it successfully integrates training in PCK to outcomes-based education. These aspects are characterized by facial height, mouth width, and facial structure, respectively.

Third-year students and irregular/extended students (those who have been in the program more than five years) show a nearly "extreme" face. According to the students, 
the worst aspects of the OBTEC trimester scheme are the inefficient use of time in pacing the lessons, the lack of school-life balance, and the difficulty in completing class requirements because of the schedule. These aspects are represented by hair height, nose width, and thin hair pointing downward.

The student responses for the different colleges are shown in Appendix 2. The Bachelor in Information Technology Education with Certificate in Teaching Elementary and the Bachelor in Library \& Information Science have "ideal" faces, while the Bachelor of Literature Education with Certificate in Teaching Junior/Senior Secondary High School, and the Bachelor in Music and Art Education with Certificate in Teaching Junior/Senior Secondary High School have "extreme" faces.

\subsection{College of Teacher Development, faculties, and institutes}

Nineteen faculty members from various faculties/programs answered the survey. The faculty members have a mean age of $42.11(\mathrm{SD}=7.92)$ years and a mean of 9.96 $(\mathrm{SD}=8.34)$ years of university service. The majority are females with the rank of assistant professor. Faculty members in the College of Teacher Development (CTD) found the OBTEC trimester scheme to be somewhat favorable (overall mean $=3.94$ somewhat agree; overall $\mathrm{SD}=0.30$ ). Figure 3 shows that the overall Chernoff face for the CTD is "ideal."

More specifically, among the CTD faculties, the Faculty of Sciences, Technology, and Mathematics shows the most "ideal" face. The most positive aspects of the OBTEC trimester scheme from the perspective of the faculty members are its consistency with the $\mathrm{K}$ to 12 curriculum, its ability to prepare students for the teaching profession, and its integration of training in pedagogical content knowledge to outcomes-based education. These aspects are characterized by facial height, mouth width, and facial structure, respectively.

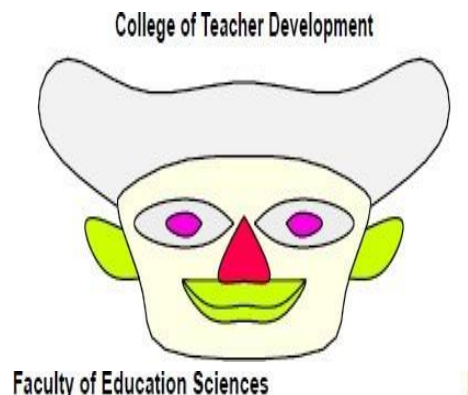

Faculty of Education Sciences

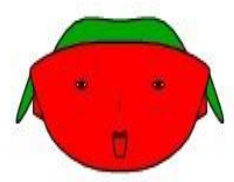

Faculty of Arts and Languages

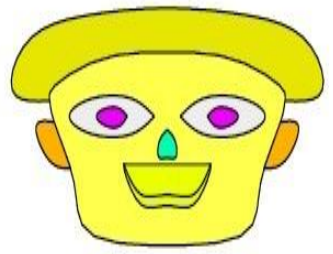

Faculty of Sciences, Technology, and Mathematics

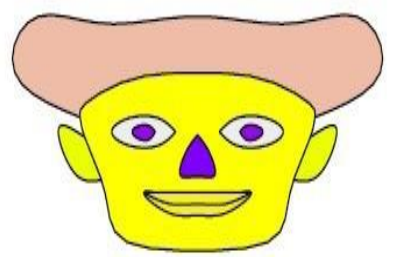

Faculty of Behavioral and Social Sciences

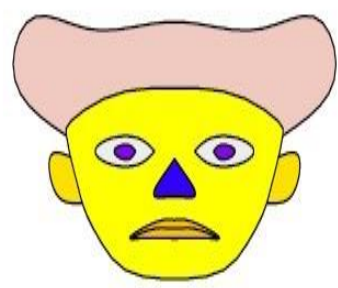

Physical Education, Health, Recreation, Dance

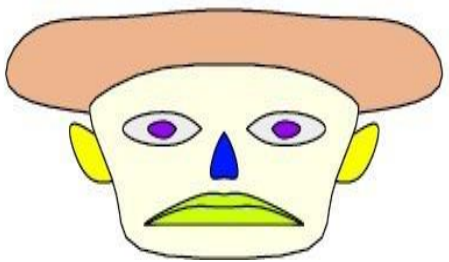

Figure 3. Chernoff faces for faculties and institutes 
The Faculty of Education Sciences shows an "extreme" face (Figure 3). The worst aspects of the trimester scheme in their view are that it makes work-life balance difficult for faculty members, that it uses time inefficiently because it is too fast-paced, and that it provides faculty members with too little time to finish all their work requirements. These aspects are characterized by nose width, hair height, and hair style, respectively.

\subsection{Faculty Members}

When grouped according to position, years of teaching, and faculty rank, the dean is found to possess an "ideal" face compared to the associate dean (Figure 4), and faculty members with less than a year of teaching experience are found to have more "ideal" features than those with 10 to 20 years of experience (Figure 5).
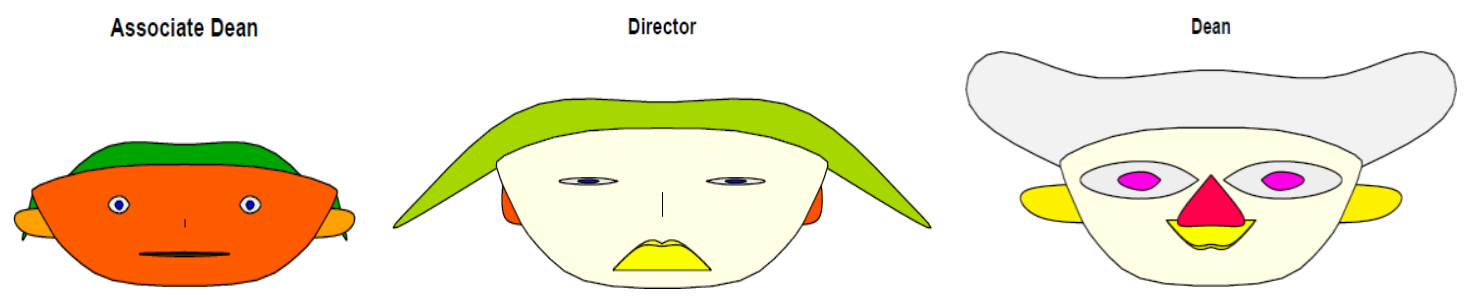

Figure 4. Chernoff faces for administrators by position

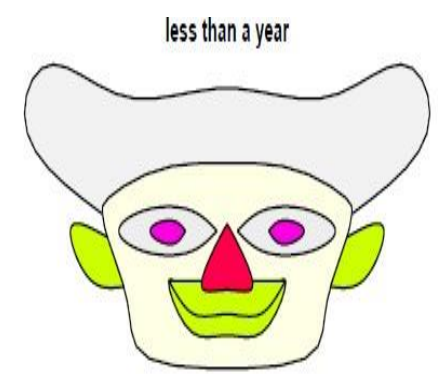

10 to 20 years

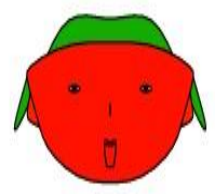

less than 5 years

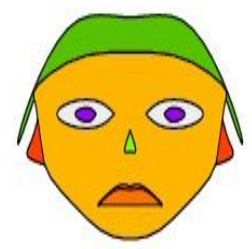

20 to 30 years

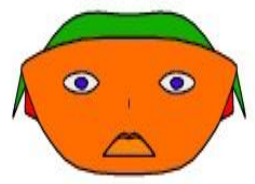

5 to 10 years

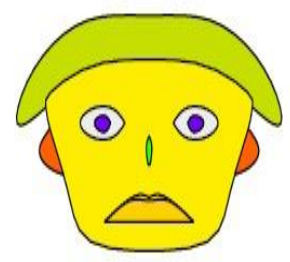

30 years or more

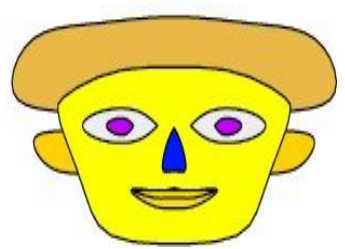

Figure 5. Chernoff faces for faculty members by years of teaching

When grouped according to rank, the Chernoff face for associate professors can be seen to possess more "ideal" features than that for full professors (Figure 6). 


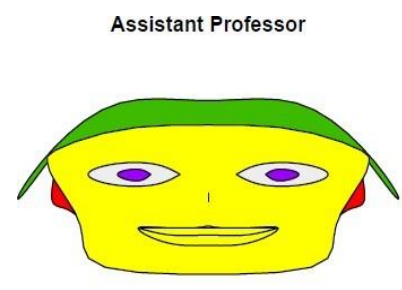

Full Professor

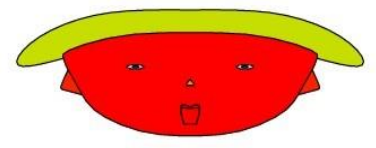

Associate Professor

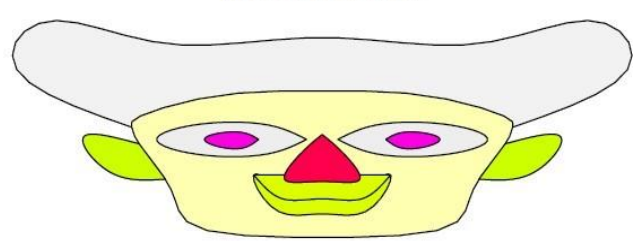

Instructor

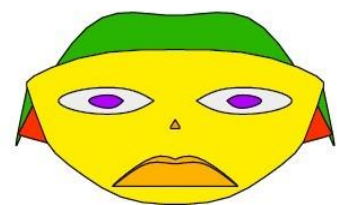

Figure 6. Chernoff faces in terms of faculty rank

\subsection{Overall Chernoff faces for students, faculty members, and administration}

Five administrators from various offices and positions answered the evaluation survey on the OBTEC trimester scheme. The administrators have a mean age of 48.8 $(\mathrm{SD}=6.94)$ years and a mean of $27(\mathrm{SD}=6.60)$ years of service. Most are females with the rank of full professor. Figure 7 shows an "ideal" face for the administrators. The administrators gave a generally favorable rating (overall mean $=4.56$ agree; overall $\mathrm{SD}=0.45)$ to the OBTEC trimester scheme. The most highly rated statements by the administrators pertain to the success of OBTEC in integrating pedagogical knowledge training into outcomes-based education, in preparing students for the teaching profession, and in being consistent with the $\mathrm{K}$ to 12 curriculum. These aspects are characterized by facial structure, mouth width, and facial height, respectively.
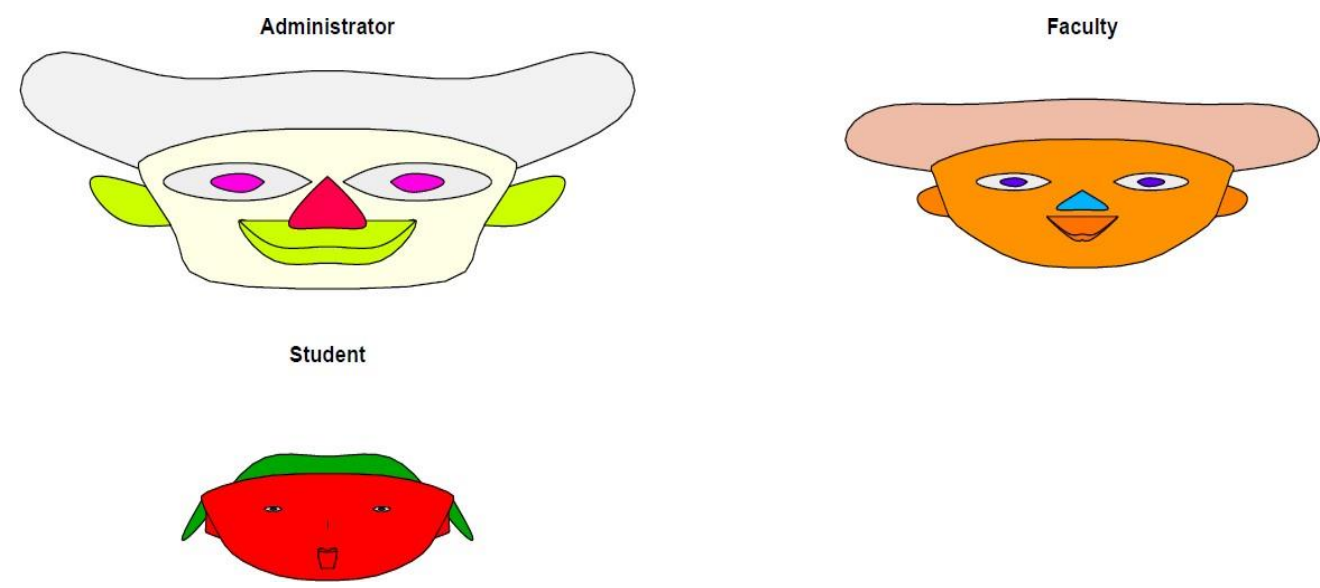

Figure 7. Chernoff faces for the overall response of students, faculty, and administrators

Despite the overall favorable rating by the administrators, the statements they agreed with least are those about the efficient use of time, the ability to meet objectives, and the ability to provide enough time to meet all administrative work requirements. These aspects are characterized by hair height, hair width, and hair style, respectively, and are not far from how the faculty and students perceived the OBTEC trimester scheme. 
The most negative aspects the faculty and students perceived were similarly characterized by nose width, hair height, and hair style.

Students possessed the "extreme" features among the three overall responses. The most negative aspects of the OBTEC trimester scheme according to the students are characterized by hair height, nose width, and thin hair pointing downward, as shown in Figure 7.

\section{CONCLUSIONS}

This study uses Chernoff faces to model the responses of students, faculty, and administrators at a teacher education institution in Manila, Philippines, on the implementation of an OBTEC trimester scheme. The overall Chernoff faces indicate positive responses among the administrators and faculty members. It has also been shown that students perceived the OBTEC trimester scheme to be somewhat inefficient in the use of time in the pacing of lessons, that school-life balance was lacking because of the trimester scheme, and that they were unable to complete their class requirements because of the schedule. These student responses are best visualized in the thin features of their Chernoff face. Based on the results of the study, it is recommended that careful planning be done to schedule the activities of the OBTEC trimester scheme to the advantage of students and faculty members. This would also allow enough time to fulfill all the objectives laid out in the OBTEC. It is not only the fulfillment of its aims that should be considered but also its effect on the well-being of the students, faculty members, and administrators. Therefore, a properly scheduled and implemented program should allow students and faculty members to enjoy, stay motivated, and experience school/work-life balance, while at the same time meeting the objectives of the OBTEC trimester scheme.

School administrators will need to use several tools, such as the Chernoff faces, to gather and analyze information about the OBTEC trimester scheme, and even use more tools to help understand and present that information to understand its implementation. It has also been shown that facial features, such as height and width of the face, structure of the face, height and width of the mouth, a smiling mouth, height and width of the eyes, height and width of hair, style of hair, height and width of the nose, and width and height of the ears can be used to represent the values of variables in the OBTEC trimester scheme. Chernoff's faces were found to be a simple, yet powerful tool to model responses in the evaluation of the OBTEC trimester scheme. Chernoff faces not only give a visual representation of responses to the OBTEC trimester scheme, but they also allow school administrators to assimilate, understand, review, and adjust the implementation of the OBTEC trimester scheme for improvement and policy enrichment.

This paper does not claim to be a definitive study of the evaluation of the OBTEC trimester scheme implementation at the teacher education institution based in Manila, Philippines. Rather, the data and graphic representations presented in this paper may well have been very different from the focus of the data, sources, or other dimensions of the $\mathrm{OBE}$ and trimester evaluation. Second, this study provides more of a snapshot resulting from the use of Chernoff faces without cultural validation of the face features. Chernoff 
faces may be interpreted differently based on which attributes are assigned to which features by the researchers. Thus, any variable assigned to the smile, for instance, would become significant.

Features of the Chernoff faces are not definitive and may vary among different groups of people and cultures. Thus, a cross-cultural validation should be made for future research. Studies, such as a happiness index among graduate and undergraduate students, can also be performed for curriculum changes at colleges and universities. Comparison between Chernoff faces at different university and college campuses can also be made regarding satisfaction, learning environment, and opportunities to learn, and the like can also be done for policy recommendations.

\section{REFERENCES}

Chen, H. M. (2017). Information visualization principles, techniques, and software. Library Technology Reports, 53(3), 8-16.

Chernoff, H. (1973). The use of faces to represent points in k-dimensional space graphically. Journal of the American Statistical Association, 68(342), 361-368. https://doi.org/10.1080/01621459.1973.10482434

Guha, A. H., \& Assaf, G. J. (2019). Representing collected road condition data with Chernoff faces for evaluation of pavement conditions. In K. Zhang \& S.-H. Chen (Eds.), Testing and Characterization of Asphalt Materials and Pavement Structures: Proceedings of the 5th GeoChina International Conference 2018 Civil Infrastructures Confronting Severe Weathers and Climate Changes: From Failure to Sustainability (pp. 136-150). Springer. https://doi.org/10.1007/978-3319-95789-0_13

Mateos, E. Y. M., Garrido, M. A. L., Hernandez, J.-A., Ortiz, C. A. O., \& González, O. (2018). Multivariate analysis of university student engagement through visualization techniques. Research in Computing Science, 147(2), 77-87. https://doi.org/10.13053/rcs-147-2-6

Moiz, S. A., \& Chillarige, R. R. (2020). Method Level Code Smells: Chernoff Face Visualization. In S. C. Satapathy, K. S. Raju, K. Shyamala, D. R. Krishna, \& M. N. Favorskaya (Eds), Advances in Decision Sciences, Image Processing, Security and Computer Vision (pp. 520-527). Springer, Cham. https://doi.org/10.1007/978 -3-030-24322-7_63

Nuñez, J. J. R. (2013). Survey on Chernoff Faces in Hungary and Austria: Further research and experiments, agreements on scientific and technological cooperation of the National Office for Research and Technology of Hungary and Federal Ministry of Science and Research. National Office for Research and Technology, Budapest, Hungary, and Federal Ministry of Education, Science and Research, Vienna, Austria.

Pitt, L. E., Mills, A. J., Chan, A., Menguc, B., \& Plangger, K. (2011, June 9-11). Using Chernoff Faces to Portray Social Media Wine Brand Images. 6th AWBR International Conference, Bordeaux Management School, BEM, France. 
Soininvaara, K. (2013). The battle of the game consoles: Utilizing Chernoff faces in modelling competitive dynamics between MNCs. Master's thesis, Aalto University School of Business, Aalto University, Greater Helsinki, Finland.

Teke, E. Ç., Koşkan, Ö., \& Köknaroğlu, H. (2020). Chernoff faces application in livestock. Ziraat Fakültesi Dergisi-Süleyman Demirel Üniversitesi, 15(1), 64-71.

VanHoudnos, N., Casey, W., French, D., Lindauer, B., Kanal, E., Wright, E., Woods, B., Moon, S., Jansen, J., \& Carbonell, J. (2017). This malware looks familiar: Laymen identify malware run-time similarity with Chernoff faces and stick figures. In T. Nakano \& A. Compagnoni (Eds.), Proceedings of the 10th EAI International Conference on Bio-inspired Information and Communications Technologies, (pp. 152-159). European Union Digital Library. https://doi.org/10.4108/eai.22-32017.152417

Zhang, H., Hou, Y., Zhao, J., Wang, L., Xi, T., \& Li, Y. (2017). Automatic welding quality classification for the spot welding based on the Hopfield associative memory neural network and Chernoff face description of the electrode displacement signal features. Mechanical Systems and Signal Processing, 85, 1035-1043. https://doi.org/10.1016/j.ymssp.2016.06.036

\section{APPENDICES}

\section{Appendix 1. Chernoff Characteristics based on Happiness Domain}

\begin{tabular}{llll}
\hline $\begin{array}{l}\text { Chernoff Face } \\
\text { Characteristics }\end{array}$ & Domain of Happiness & & \\
\cline { 2 - 4 } & $\begin{array}{l}\text { Students Questions } \\
\text { Responses }\end{array}$ & $\begin{array}{l}\text { Faculty Questions } \\
\text { Responses }\end{array}$ & $\begin{array}{l}\text { Administration Questions } \\
\text { Responses }\end{array}$ \\
\hline Height of face & $\begin{array}{l}\text { 1. The OBTEC curriculum } \\
\text { is consistent with the K to } \\
12 \text { curriculum. }\end{array}$ & $\begin{array}{l}\text { 1. The OBTEC curriculum } \\
\text { is consistent with the K to } \\
12 \text { curriculum. }\end{array}$ & $\begin{array}{l}\text { 1. The OBTEC curriculum is } \\
\text { consistent with the K to } 12 \\
\text { curriculum. }\end{array}$ \\
Width of face & $\begin{array}{l}\text { 2. The OBTEC curriculum } \\
\text { ensures the students' } \\
\text { mastery of all the necessary } \\
\text { competencies. }\end{array}$ & $\begin{array}{l}\text { 2. The OBTEC curriculum } \\
\text { ensures the students } \\
\text { mastery of all the necessary } \\
\text { competencies. }\end{array}$ & $\begin{array}{l}\text { 2. The OBTEC curriculum } \\
\text { ensures the students' mastery } \\
\text { of all the necessary } \\
\text { competencies. }\end{array}$ \\
\cline { 2 - 3 } Structure of face & $\begin{array}{l}\text { 3. The OBTEC curriculum } \\
\text { successfully integrates } \\
\text { training in pedagogical } \\
\text { content knowledge to } \\
\text { outcomes-based education } \\
\text { (e.g., students demonstrate } \\
\text { mastery in science and have } \\
\text { the ability to teach science). }\end{array}$ & $\begin{array}{l}\text { 3. The OBTEC curriculum } \\
\text { successfully integrates } \\
\text { training in pedagogical } \\
\text { content knowledge to } \\
\text { outcomes-based education } \\
\text { (e.g., students demonstrate } \\
\text { mastery in science and have } \\
\text { the ability to teach science). }\end{array}$ & $\begin{array}{l}\text { 3. The OBTEC curriculum } \\
\text { successfully integrates } \\
\text { training in pedagogical } \\
\text { content knowledge to } \\
\text { outcomes- based education } \\
\text { (e.g., students demonstrate } \\
\text { mastery in science and have } \\
\text { the ability to teach science). }\end{array}$ \\
\hline
\end{tabular}

Note: Responses: Strongly Agree (6), Agree (5), Somewhat Agree (4), Somewhat Disagree (3), Disagree (2), Strongly Disagree (1). 


\section{Appendix 1. Chernoff Characteristics based on Happiness Domain (cont.)}

\begin{tabular}{|c|c|c|c|}
\hline \multirow{2}{*}{$\begin{array}{l}\text { Chernoff Face } \\
\text { Characteristics }\end{array}$} & \multicolumn{3}{|l|}{ Domain of Happiness } \\
\hline & $\begin{array}{l}\text { Students Questions } \\
\text { Responses }\end{array}$ & $\begin{array}{l}\text { Faculty Questions } \\
\text { Responses }\end{array}$ & $\begin{array}{l}\text { Administration Questions } \\
\text { Responses }\end{array}$ \\
\hline Height of mouth & $\begin{array}{l}\text { 4. The OBTEC curriculum } \\
\text { prepares the students for the } \\
\text { Board Licensure } \\
\text { Examination for } \\
\text { Professional Teachers } \\
\text { (BLEPT). }\end{array}$ & $\begin{array}{l}\text { 4. The OBTEC curriculum } \\
\text { prepares the students for the } \\
\text { Board Licensure } \\
\text { Examination for } \\
\text { Professional Teachers } \\
\text { (BLEPT). }\end{array}$ & $\begin{array}{l}\text { 4. The OBTEC curriculum } \\
\text { prepares the students for the } \\
\text { Board Licensure Examination } \\
\text { for Professional Teachers } \\
\text { (BLEPT). }\end{array}$ \\
\hline Width of mouth & $\begin{array}{l}\text { 5. The OBTEC curriculum } \\
\text { prepares the students for the } \\
\text { teaching profession. }\end{array}$ & $\begin{array}{l}\text { 5. The OBTEC curriculum } \\
\text { prepares the students for the } \\
\text { teaching profession. }\end{array}$ & $\begin{array}{l}\text { 5. The OBTEC curriculum } \\
\text { prepares the students for the } \\
\text { teaching profession. }\end{array}$ \\
\hline Smiling & $\begin{array}{l}\text { 6. The flexible learning } \\
\text { activities complement the } \\
\text { activities during actual } \\
\text { contact time. }\end{array}$ & $\begin{array}{l}\text { 6. The flexible learning } \\
\text { activities complement the } \\
\text { activities during actual } \\
\text { contact time. }\end{array}$ & $\begin{array}{l}\text { 6. The flexible learning } \\
\text { activities complement the } \\
\text { activities during actual contact } \\
\text { time. }\end{array}$ \\
\hline Height of eyes & $\begin{array}{l}\text { 7. The flexible learning } \\
\text { activities are an innovation } \\
\text { to the traditional classroom } \\
\text { learning. }\end{array}$ & $\begin{array}{l}\text { 7. The flexible learning } \\
\text { activities are an innovation } \\
\text { to the traditional classroom } \\
\text { learning. }\end{array}$ & $\begin{array}{l}\text { 7. The flexible learning } \\
\text { activities are an innovation to } \\
\text { the traditional classroom } \\
\text { learning. }\end{array}$ \\
\hline Width of eyes & $\begin{array}{l}\text { 8. The flexible learning } \\
\text { activities allow students to } \\
\text { apply what they learned in } \\
\text { the classroom. }\end{array}$ & $\begin{array}{l}\text { 8. The flexible learning } \\
\text { activities allow students to } \\
\text { apply what they learned in } \\
\text { the classroom. }\end{array}$ & $\begin{array}{l}\text { 8. The flexible learning } \\
\text { activities allow students to } \\
\text { apply what they learned in the } \\
\text { classroom. }\end{array}$ \\
\hline Height of hair & $\begin{array}{l}\text { 9. The OBTEC trimester } \\
\text { scheme allows the efficient } \\
\text { use of time in terms of } \\
\text { pacing of the lessons. }\end{array}$ & $\begin{array}{l}\text { 9. The OBTEC trimester } \\
\text { scheme allows the efficient } \\
\text { use of time in terms of } \\
\text { pacing of the lessons. }\end{array}$ & $\begin{array}{l}\text { 9. The OBTEC trimester } \\
\text { scheme allows the efficient } \\
\text { use of time in terms of } \\
\text { program activities. }\end{array}$ \\
\hline Width of hair & $\begin{array}{l}\text { 10. The OBTEC trimester } \\
\text { scheme allows all the } \\
\text { course objectives to be met. }\end{array}$ & $\begin{array}{l}\text { 10. The OBTEC trimester } \\
\text { scheme allows all the } \\
\text { course objectives to be met. }\end{array}$ & $\begin{array}{l}\text { 10. The OBTEC trimester } \\
\text { scheme allows all the program } \\
\text { objectives to be met. }\end{array}$ \\
\hline Style of hair & $\begin{array}{l}\text { 11. The OBTEC trimester } \\
\text { scheme provides students } \\
\text { enough time to complete all } \\
\text { the class requirements. }\end{array}$ & $\begin{array}{l}\text { 11. The OBTEC trimester } \\
\text { scheme provides faculty } \\
\text { members enough time to } \\
\text { complete all the work } \\
\text { requirements. }\end{array}$ & $\begin{array}{l}\text { 11. The OBTEC trimester } \\
\text { scheme provides } \\
\text { administrators enough time to } \\
\text { complete all the work } \\
\text { requirements. }\end{array}$ \\
\hline Height of nose & $\begin{array}{l}\text { 12. The OBTEC trimester } \\
\text { scheme allows students to } \\
\text { have a better appreciation of } \\
\text { learning. }\end{array}$ & $\begin{array}{l}\text { 12. The OBTEC trimester } \\
\text { scheme allows faculty } \\
\text { members to have a better } \\
\text { appreciation of teaching. }\end{array}$ & $\begin{array}{l}\text { 12. The OBTEC trimester } \\
\text { scheme allows administrators } \\
\text { to have a better appreciation } \\
\text { of their job. }\end{array}$ \\
\hline Width of nose & $\begin{array}{l}\text { 13. The OBTEC trimester } \\
\text { scheme allows students to } \\
\text { experience school-life } \\
\text { balance. }\end{array}$ & $\begin{array}{l}\text { 13. The OBTEC trimester } \\
\text { scheme allows faculty } \\
\text { members to experience } \\
\text { work-life balance. }\end{array}$ & $\begin{array}{l}\text { 13. The OBTEC trimester } \\
\text { scheme allows administrators } \\
\text { to experience work-life } \\
\text { balance. }\end{array}$ \\
\hline
\end{tabular}

Note: Responses: Strongly Agree (6), Agree (5), Somewhat Agree (4), Somewhat Disagree (3), Disagree (2), Strongly Disagree (1). 


\section{Appendix 1. Chernoff Characteristics based on Happiness Domain (cont.)}

\begin{tabular}{|c|c|c|c|}
\hline \multirow{2}{*}{$\begin{array}{l}\text { Chernoff } \\
\text { Characteristics in } \\
\text { Faces }\end{array}$} & \multicolumn{3}{|l|}{ Domain of Happiness } \\
\hline & $\begin{array}{l}\text { Students Questions } \\
\text { Responses }\end{array}$ & $\begin{array}{l}\text { Faculty Questions } \\
\text { Responses }\end{array}$ & $\begin{array}{l}\text { Administration Questions } \\
\text { Responses }\end{array}$ \\
\hline Width of ears & $\begin{array}{l}\text { 14. The OBTEC trimester } \\
\text { scheme motivates students } \\
\text { to do well in their studies. }\end{array}$ & $\begin{array}{l}\text { 14. The OBTEC trimester } \\
\text { scheme motivates faculty } \\
\text { members to do well in their } \\
\text { teaching. }\end{array}$ & $\begin{array}{l}\text { 14. The OBTEC trimester } \\
\text { scheme motivates } \\
\text { administrators to do well in } \\
\text { their job. }\end{array}$ \\
\hline Height of ears & $\begin{array}{l}\text { 15. The OBTEC trimester } \\
\text { scheme allows students to } \\
\text { experience academic } \\
\text { satisfaction. }\end{array}$ & $\begin{array}{l}\text { 15. The OBTEC trimester } \\
\text { scheme allows faculty } \\
\text { members to experience } \\
\text { work satisfaction. }\end{array}$ & $\begin{array}{l}\text { 15. The OBTEC trimester } \\
\text { scheme allows administrators } \\
\text { to experience work } \\
\text { satisfaction. }\end{array}$ \\
\hline
\end{tabular}

Note: Responses: Strongly Agree (6), Agree (5), Somewhat Agree (4), Somewhat Disagree (3), Disagree (2), Strongly Disagree (1).

\section{Appendix 2. Chernoff faces for various educational programs}
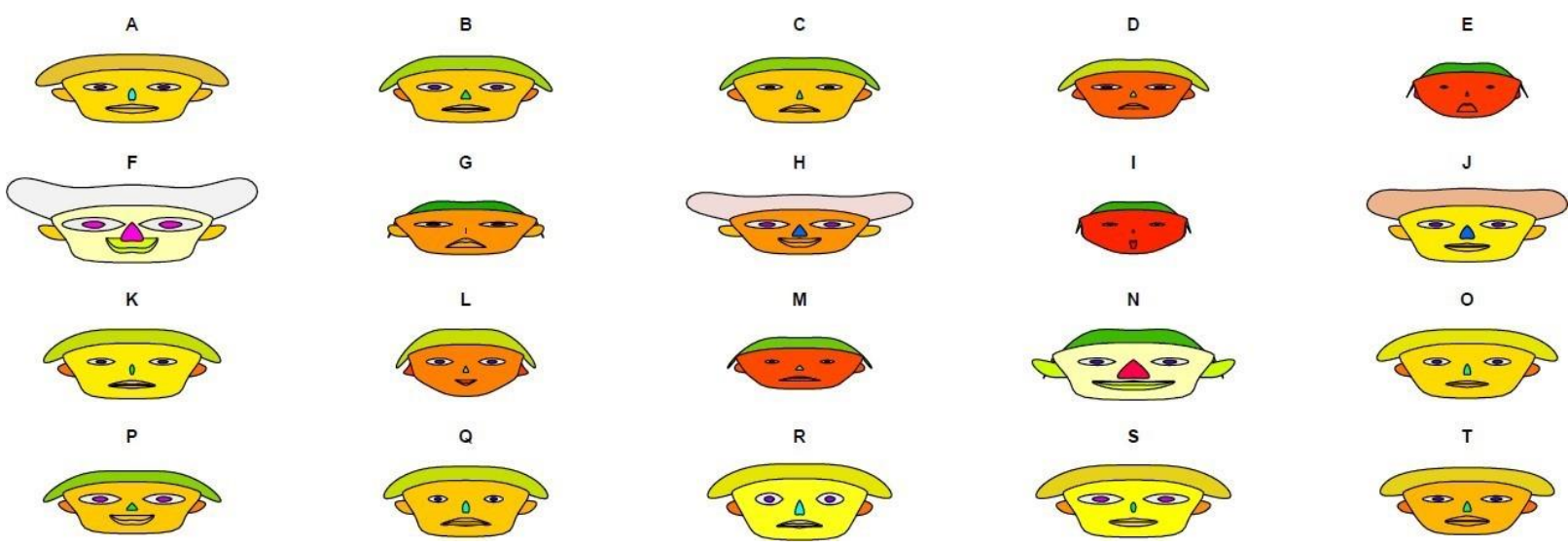

\begin{tabular}{ll}
\hline Letters & Program \\
\hline A & Bachelor in Early Childhood Education \\
B & Bachelor in English Education with Certificate in Teaching Elementary \\
C & Bachelor in English Education with Certificate in Teaching Junior/Senior Secondary High School \\
D & Bachelor in Filipino Education with Certificate in Teaching Elementary \\
E & Bachelor in Filipino Education with Certificate in Teaching Junior/Senior Secondary High School \\
F & Bachelor in Information Technology Education with Certificate in Teaching Elementary \\
G & Bachelor in Information Technology Education with Junior/Senior Secondary High School \\
H & Bachelor in Library and Information Science \\
I & Bachelor in Literature Education with Certificate in Teaching Junior/Senior Secondary High School \\
J & Bachelor in Mathematics and Science Elementary Education \\
\hline
\end{tabular}




\begin{tabular}{|c|c|}
\hline Letters & Program \\
\hline K & Bachelor in Mathematics Education with Certificate in Teaching Junior/Senior Secondary High School \\
\hline $\mathrm{L}$ & Bachelor in Music and Art Education with Certificate in Teaching Elementary \\
\hline M & Bachelor in Music and Art Education with Certificate in Teaching Junior/Senior Secondary High School \\
\hline $\mathrm{N}$ & Bachelor in Physical and Health Education \\
\hline $\mathrm{O}$ & $\begin{array}{l}\text { Bachelor in Science Education with Specialization in Biology with Certificate in Teaching Junior/Senior } \\
\text { Secondary High School }\end{array}$ \\
\hline $\mathrm{P}$ & $\begin{array}{l}\text { Bachelor in Science Education with Specialization in Chemistry with Certificate in Teaching } \\
\text { Junior/Senior Secondary High School }\end{array}$ \\
\hline Q & $\begin{array}{l}\text { Bachelor in Science Education with Specialization in Physics with Certificate in Teaching Junior/Senior } \\
\text { Secondary High School }\end{array}$ \\
\hline $\mathrm{R}$ & Bachelor in Social Science Education with Certificate in Teaching Junior/Senior Secondary High School \\
\hline S & Bachelor in Values Education with Certificate in Teaching Junior/Senior Secondary High School \\
\hline $\mathrm{T}$ & Bachelor of Science/Master of Arts in Psychology - Guidance and Counseling Straight Program \\
\hline
\end{tabular}

